\title{
Defisit Neraca Perdagangan: J-Curve, Perang Dagang dan Model Salter Corden ${ }^{\star}$
}

\author{
Muhammad Firdaus ${ }^{\mathrm{a}, *}$, Rini Satriani ${ }^{\mathrm{b}}$, Syarifah Amaliah ${ }^{\mathrm{a}}$, Fahmi Ahmad Salamª, \\ \& Muhammad Fazria \\ ${ }^{a}$ Departemen Ilmu Ekonomi, Fakultas Ekonomi dan Manajemen, Institut Pertanian Bogor \\ ${ }^{b}$ Lembaga Pembiayaan Ekspor Indonesia (LPEI)
}

\begin{abstract}
Exchange rate fluctuations and external shocks such as the trade war are predicted to put pressure on Indonesia's trade balance. Based on VECM analysis, the exchange rate and Indonesia's aggregate trade balance followed the J-Curve. Additionally, the trade war had impact on Rupiah depreciation and trade balance. The study also confirms eight export-oriented industries that are resilient to shocks and classified into four behaviors: (i) industries following the J-Curve; (ii) industries following the J-Curve in the long run; (iii) industriy which are not fully confirmed J-Curve, and (iv) Rest sector. The implication of this study emphasize the development of export-oriented and labor-intensive industries (Salter-Corden model).
\end{abstract}

Keywords: J Curve; exchange rate; trade war; Salter Coden Model; VECM

\begin{abstract}
Abstrak
Pergerakan nilai tukar Rupiah dan guncangan eksternal seperti perang dagang diprediksi akan memberikan tekanan terhadap neraca perdagangan. Berdasarkan analisis VECM, nilai tukar rupiah dan neraca perdagangan Indonesia secara agregat mengikuti fenomena J-Curve. Perang dagang terbukti memengaruhi depresiasi nilai tukar Rupiah dan neraca perdagangan Indonesia. Terdapat delapan industri berorientasi ekspor yang memiliki resiliensi terhadap guncangan dan diklasifikasikan menjadi empat, yakni: (i) Kelompok industri yang mengikuti fenomena J-Curve sepenuhnya; (ii) Kelompok industri dengan fenomena J-Curve pada jangka panjang; (iii) Kelompok industri yang tidak sepenuhnya mengikuti fenomena J-Curve, dan (iv) Industri lainnya. Implikasi studi ini menekankan pengembangan industri yang berorientasi ekspor dan intensif tenaga kerja (Salter-Corden model).
\end{abstract}

Kata Kunci: J Curve; nilai tukar; perang dagang; Salter Coden Model; VECM JEL Classification: E44; F140; F410

^Artikel ini bagian dari Studi “Dampak Pergerakan Nilai Tukar Rupiah terhadap Aktivitas Ekspor dan Impor Nasional" yang didanai oleh Lembaga Pembiayaan Ekspor Indonesia tahun 2018.

*Penulis Korespondensi: Departemen Ilmu Ekonomi, Fakultas Ekonomi dan Manajemen, Institut Pertanian Bogor. Gedung FEM Baru, Jalan Agatis, Kampus IPB Dramaga, Bogor 16680. E-mail: mfirdaus@ipb.ac.id; firdausfemipb@yahoo.co.id. 


\section{Pendahuluan}

Tren perubahan nilai tukar rupiah terhadap US\$ telah berlangsung sejak akhir 2017 dan diduga oleh Bank Indonesia akan berlanjut hingga akhir 2018. Pergerakan nilai tukar rupiah menurut Bank Dunia mempunyai tingkat volatilitas yang lebih tinggi dibandingkan tahun sebelumnya, dan memiliki tendensi pergerakan yang lebih besar dibandingkan dengan mata uang negara lain di Asia. Hal ini memang bukan fenomena ekonomi baru, namun seberapa besar dampak yang ditimbulkan dari pergerakan nilai tukar rupiah tersebut, khususnya pada dinamika ekspor dan impor nasional, perlu dikaji secara lebih mendalam.

Terdapat dua preposisi terhadap dampak pergerakan nilai tukar rupiah. Pertama, depresiasi nilai tukar rupiah mempunyai dampak positif terhadap permintaan ekspor sehingga neraca perdagangan meningkat. Secara komparatif, produk Indonesia akan lebih murah dibandingkan negara pesaing. Leigh et al. (2016) mengestimasi dampak depresiasi nilai tukar sebesar 10\% akan menyebabkan kenaikan neraca perdagangan secara rata-rata sebesar 1,5\%. Kedua, nilai tukar rupiah yang mengalami depresiasi akan berdampak negatif terhadap neraca perdagangan. Ini disebabkan oleh tingginya kandungan impor pada industri yang berorientasi ekspor sehingga depresiasi nilai tukar rupiah menurunkan kemampuan produksi dan ekspor produk ke pasar global. Dua ekspektasi yang bersifat inkonklusif ini menghendaki pembuktian secara empiris dan akurat sehingga jawaban yang shahih tentang dampak pergerakan nilai tukar rupiah dapat diperoleh. Beberapa studi terdahulu masih memberikan kesimpulan yang inkonklusif. Analisis dengan menggunakan metode kuantitatif perlu dilakukan secara mendalam, baik secara agregat maupun sektoral. Secara spesifik, studi ini bertujuan untuk:

1. Mengestimasi hubungan pergerakan nilai tukar terhadap neraca perdagangan Indonesia;

2. Menganalisis dampak perang dagang terhadap neraca perdagangan Indonesia;

3. Mengidentifikasi pengembangan industri berorientasi ekspor.

\section{Tinjauan Literatur}

Penelitian mengenai pergerakan dan volatilitas nilai tukar telah banyak dilakukan. Rose (1990) menggambarkan bahwa nilai tukar tidak memengaruhi neraca pendapatan di lima negara OECD pasca era Bretton woods. Rose dan Yellen (1989) tidak dapat menolak hipotesis bahwa nilai tukar riil secara statistik tidak signifikan menentukan arus perdagangan. Mereka menguji arus perdagangan bilateral antara Amerika Serikat (AS) dengan negara-negara OECD lainnya dengan menggunakan data kuartalan.

Arize et al. (2000) melakukan penelitian tentang volatilitas nilai tukar terhadap perdagangan luar negeri di 13 negara sedang berkembang sepanjang tahun 19731996. Secara umum diperoleh hasil volatilitas nilai tukar berpengaruh negatif 
terhadap permintaan ekspor, baik dalam jangka pendek maupun jangka panjang. Penelitian yang dilakukan oleh Sabuhi-Sabouni dan Piri (2008) tentang pengaruh volatilitas terhadap ekspor sektor pertanian menunjukkan ditemukannya hasil yang berbeda. Volatilitas nilai tukar ternyata berdampak positif dalam jangka panjang terhadap ekspor sektor pertanian di Iran.

Onafowora (2003) meneliti pengaruh perubahan nilai tukar riil terhadap neraca perdagangan riil. Objek penelitian adalah negara di kawasan ASEAN, Malaysia, Indonesia, dan Thailand dengan negara-negara Amerika dan Jepang, dengan menggunakan VECM (Vector Error Correction Model). Hasil yang didapatkan menunjukkan hubungan positif jangka panjang antara nilai tukar riil dan neraca perdagangan di semua kasus: Indonesia-Jepang $(0,351)$, Indonesia-AS $(0,243)$, Malaysia-Jepang $(1,252)$, Malaysia-AS $(0,644)$, Thailand-Jepang $(1,082)$, dan Thailand-AS $(1,665)$. Estimasi untuk Malaysia-AS, Indonesia-AS, dan Indonesia-Jepang menunjukkan bahwa neraca perdagangan riil mempunyai hubungan yang negatif dengan pendapatan domestik riil dan hubungan yang positif dengan pendapatan luar negeri riil dalam jangka panjang. Akan tetapi, neraca perdagangan riil dalam model Malaysia-Jepang, Thailand-AS, dan ThailandJepang menggambarkan hasil yang berbeda, hubungan yang positif dengan pendapatan domestik riil dan hubungan yang negatif dengan pendapatan luar negeri riil.

Berdasarkan penelitian sebelumnya di beberapa negara berkembang bahwa tidak semua fenomena J-Curve ini terjadi pada saat terjadinya depresiasi mata uang. Bahmani-Oskooee dan Kantipong (2001) meneliti bahwa dari lima mitra dagang Thailand, hanya AS dan Jepang yang menunjukkan adanya fenomena JCurve. Wilson (2001) menyatakan bahwa tidak ditemukannya fenomena J-Curve antara Singapura, Korea, dan Malaysia dengan partner dagang AS dan Jepang, kecuali hubungan perdagangan antara Korea dan AS. Petrović dan Gligorić (2010) menyatakan bahwa depresiasi nilai tukar mata uang di Serbia meningkatkan neraca perdagangan pada jangka panjang dan memburuk pada jangka pendek.

Penelitian fenomena J-Curve di Indonesia sebelumnya telah dilakukan oleh Bahmani-Oskooee dan Harvey (2009) menggunakan data kuartalan dari kuartal 1 tahun 1974 hingg kuartal IV tahun 2008 dengan metode bound testing dan Error Correction Models, disimpulkan bahwa fenomena J-Curve hanya terjadi pada hubungan dagang antara Indonesia dengan Kanada, Jepang, Singapura, Malaysia, dan U.K.

Sedangkan, Ramadona (2016) menggunakan data dengan periode waktu bulanan di mana mitra dagang Indonesia yang terkait dalam penelitian merupakan 10 mitra dagang terbesar Indonesia pada tahun 2014 diurutkan berdasarkan total perdagangannya. Adapun metode yang digunakan dalam penelitian ialah dengan menggunakan metode Panel FMOLS dan Panel ECM. Hasil yang didapatkan bahwa belum ada fenomena J-Curve di Indonesia. 


\section{Metode Penelitian}

Untuk menjawab tujuan kajian, beberapa alat analisis diterapkan yang bersifat melengkapi satu sama lainnya. Dua pendekatan digunakan, yaitu pertama pendekatan model ekonometrika untuk menangkap fenomena historikal pergerakan nilai tukar rupiah dan menganalisis faktor-faktor yang memengaruhi ekspor Indonesia. Dua model ekonometrika yang digunakan, yaitu VECM dan regresi panel spasial. Kedua, simulasi dengan menggunakan GTAP. Dengan menggunakan analisis ini, maka dampak pergerakan nilai tukar rupiah dapat dilihat secara sektoral untuk menghasilkan rekomendasi industri berorientasi ekspor yang merespons positif pergerakan nilai tukar Rupiah.

\subsection{Pendekatan VECM untuk Model J-Curve}

VECM merupakan model bentuk VAR yang terestriksi (Enders, 2004). Model ini digunakan untuk data yang nonstasioner tetapi memiliki potensi untuk terkointegrasi. Restriksi tambahan ini harus diberikan karena keberadaan bentuk data yang tidak stasioner pada level, tetapi terkointegrasi. Data time series cenderung memiliki stasioneritas pada tingkat first differences. VECM dapat memberikan informasi mengenai tingkah laku jangka pendek suatu variabel terhadap jangka panjangnya akibat adanya perubahan yang permanen. Adapun persamaan umum model VECM menurut Ward dan Siregar (2000) dapat dilihat sebagai berikut:

$$
\Delta y_{t}=\sum_{i=1}^{k-1} \Gamma i \Delta y_{t-1}+\mu_{0}+\mu_{1} t+\alpha \beta^{\prime} y_{t-1}+\varepsilon_{t}
$$

Dimana:

$\Delta y t=$ yt-yt-1

$y t$ : vektor yang berisi variabel yang dianalisis (variabel level)

$\Gamma i$ : matriks koefisien regresi

$\mu 1$ : vektor koefisien regresi

$\beta^{\prime}$ : vektor kointegrasi

$(k-1)$ : ordo VECM dari VAR

$\mu 0$ : vektor intersep

$\alpha:$ matriks loading

et : error term

Model yang akan digunakan dalam penelitian ini mengacu pada penelitian Ramakrishnan et al. (1999) dengan fungsi, yaitu:

$$
\ln X M_{t}=a_{0}+a_{1} \ln N E E R_{t}+a_{2} Y_{t}+a_{3} Y_{t}^{*}+\varepsilon_{t}
$$

Dimana:

$X M_{t}$ : Neraca Perdagangan

$N E E R_{t}$ : Nilai Tukar Rupiah terhadap Dolar

$Y_{t}:$ Gross Domestic Product (USD) 
$Y_{t}^{*}:$ Gross Domestic Product (USD) Negara Mitra

Dalam penelitian ini, data yang digunakan adalah data kuartalan dari tahun 2010 hingga 2017.

\subsection{Regresi Panel Spasial}

Data panel adalah gabungan dari data time series dan cross section. Penggunaan metode data panel sudah banyak dipakai saat ini sebab adanya kelemahan dalam pendekatan metode cross section saja atau pendekatan time series. Jika hanya menggunakan metode cross section, pengamatan yang diamati hanya pada titik tertentu saja sehingga perkembangan pengamatan tersebut dalam kurun waktu tertentu tidak dapat diestimasi. Pendekatan metode time series juga menimbulkan persoalan, yaitu variabel-variabel yang diobservasi secara agregat hanya dari satu unit individu sehingga memberi peluang untuk menghasilkan estimasi yang sifatnya bias.

Data di tingkat antar negara cenderung tidak independen antar tiap wilayah (cross section) karena adanya kemiripan di antara wilayah yang bertetangga. Akibatnya, prosedur estimasi standar tanpa mempertimbangkan faktor interaksi antar wilayah di berbagai studi empiris dapat menjadi tidak valid serta menyebabkan hasil estimasi bias dan inefisien (Arbia et al., 2005). Masalah interaksi antar wilayah ini diabaikan pada studi panel biasa. Menurut LeSage dan Pace (2009), akibat dari mengabaikan interaksi spasial pada variabel dependen maupun independen cukup besar karena literatur ekonometrika telah menunjukkan bahwa jika ada variabel bebas yang relevan yang tidak dimasukkan ke dalam persamaan regresi, maka pendugaan koefisien dari variabel-variabel lainnya menjadi bias dan inkonsisten.

Model spasial dibentuk dari model regresi linier dengan menambahkan pengaruh interaksi spasial ke dalam model. Secara umum, terdapat tiga jenis pengaruh interaksi di dalam model ekonometrika spasial, yaitu efek interaksi endogen antar variabel dependen (Y), efek interaksi antar variabel bebas (X), dan efek interaksi antar komponen error ( $\varepsilon$ ) (Elhorst, 2014). Salah satu model spasial adalah spatial lag model atau spatial autoregressive (SAR), yang memperhitungkan efek interaksi endogen antar variabel dependen. Bentuk spatial lag model ditunjukkan pada persamaan berikut:

$$
y_{i t}=\rho \sum_{j=1}^{n} w_{i j} y_{j t}+x_{i t} \beta+\mu_{i}+\varepsilon_{i t}
$$

di mana $\rho$ disebut koefisien autoregresif spasial dan $w_{i j}$ adalah elemen dari matriks pembobot $W$ yang mendeskripsikan susunan spasial dari unit-unit yang terdapat di dalam model. Keterbatasan model SAR adalah pola spasial dalam data hanya dapat dijelaskan oleh interaksi endogen, tetapi tidak dapat dijelaskan oleh interaksi variabel bebas. Model SAR dapat dikembangkan dengan menambah lag spasial dari variabel bebas yang dikenal sebagai Spatial Durbin Model 
(SDM) dengan bentuk model sebagai berikut:

$$
y_{i t}=\rho \sum_{j=1}^{n} w_{i j} y_{j t}+x_{i t} \beta+=\gamma \sum_{j=1}^{n} w_{i j} x_{i j t}+\mu_{i}+\varepsilon_{i t}
$$

Matriks pembobot spasial adalah salah satu cara termudah untuk meringkas adanya hubungan spasial di dalam data. Matriks pembobot spasial berbentuk matriks non-negatif berukuran $n x n$ yang menentukan set tetangga untuk bagi tiap unit spasial (lokasi). Bobot spasial mencirikan adanya ketergantungan antar lokasi (cross-section dependence) sehingga ukuran bobot spasial memiliki pengaruh penting pada estimasi model ketergantungan spasial (Jajang et al., 2013). Dalam penelitian ini digunakan matriks pembobot spasial berdasarkan kondisi geografis yaitu matriks kebalikan jarak (inverse distance) dan hubungan ekonomi, yaitu perdagangan bilateral. Pembobotan dengan matriks invers jarak memberikan nilai bobot yang besar untuk dua negara dengan jarak yang lebih dekat dan pembobotan dengan matriks perdagangan bilateral memberikan bobot yang lebih besar untuk dua negara dengan total nilai perdagangan yang lebih besar.

Data yang digunakan dalam pemodelan regresi panel spasial adalah data 30 negara tujuan ekspor terbesar Indonesia dengan periode waktu tahun 2000-2018. Variabel respons adalah total nilai ekspor Indonesia ke negara tujuan. Variabel bebas dalam penelitian ini antara lain: gross domestic product (GDP) negara tujuan, nilai tukar (dihitung dari nilai tukar negara tujuan terhadap US Dollar dibagi nilai tukar Rupiah terhadap USD), dan tarif. Lag spasial dari variabel dependen dan bebas disertakan dalam model untuk menangkap pengaruh variabel antar wilayah. Data bersumber dari World Integrated Trade Solution (WITS).

\subsection{GTAP Model}

Dalam menganalisis dampak pergerakan, analisis ini menggunakann Database Global Trade Analysis Project (GTAP) (Versi 9.0) dan model GTAP standar. Model GTAP standar mengadopsi permodelan Computable General Equilibrium (CGE) merupakan model ekonomi model multiwilayah dan multisektor dengan asumsi pasar persaingan sempurna dan constant return to scale. Database GTAP menggabungkan data perdagangan, transportasi, dan hambatan perdagangan terperinci yang mencirikan keterkaitan ekonomi antar kawasan bersama dengan basis data input-output masing-masing negara yang memperhitungkan keterkaitan antar sektor. Agregasi sektoral yang digunakan untuk keperluan analisis disusun berdasarkan klasifikasi sektor detail yang ada di GTAP, meliputi 57 sektor barang dan jasa. Simulasi operasional yang dilakukan adalah depresiasi nilai tukar Rupiah sebesar 10 persen disertai kenaikan harga impor sebesar 5 persen. Justifikasi magnitude yang digunakan untuk depresiasi nilai tukar Rupiah adalah sebesar -10 persen (ekuivalen dengan pelemahan nilai tukar Rupiah Rp13.400/USD menjadi Rp14.500/USD) serta peningkatan import price index sebesar 5 persen yang ditentukan secara arbitrary. 


\section{Hasil dan Pembahasan}

\subsection{Dampak Agregat Pergerakan Nilai Tukar terhadap Neraca Perdagangan: Analisis J-Curve}

Untuk membuktikan ada tidaknya fenomena J-Curve dalam perekonomian Indonesia, maka dalam penelitian ini dilakukan analisis J-Curve agregat perdagangan. J-Curve agregat ditujukan untuk menganalisis hubungan antara nilai tukar nominal efektif Indonesia terhadap neraca perdagangan seluruh komoditas Indonesia ke dunia internasional. Secara agregat, fenomena J-Curve di Indonesia dapat dibuktikan dari hasil estimasi model Error Correction Model (ECM) berikut. Dalam jangka pendek, perubahan nilai tukar nominal efektif memberikan pengaruh negatif yang signifikan terhadap neraca berjalan (rasio ekspor terhadap impor). Namun, Hasil estimasi ECM menunjukkan bahwa dalam jangka panjang menunjukkan terdapat penyesuaian antara variabel nilai tukar nominal efektif dengan neraca berjalan di mana neraca berjalan Indonesia dipengaruhi secara signifikan oleh nilai tukar nominal efektif serta kondisi ekonomi dalam dan luar negeri.

Tabel 1 menunjukkan bahwa koefisien jangka panjang antara NEER dengan neraca perdagangan adalah sebesar 1,0001, artinya setiap terjadi depresiasi nilai tukar nominal efektif Indonesia sebesar satu persen, dalam jangka panjang akan mengakibatkan kenaikan rasio ekspor terhadap impor sebesar 1.0001 persen. Dengan kata lain, depresiasi nilai tukar akan mendorong kenaikan ekspor serta menurunkan impor. Menurut Darwanto (2014), fenomena J-Curve dapat terjadi di Indonesia, disebabkan elastisitas impor jauh lebih tinggi dibandingkan dibandingkan dengan elatisitas ekspor sehingga fenomena J-Curve pada jangka panjang depresiasi akan menyebabkan peningkatan nilai tukar disebabkan oleh adanya penurunan impor jauh lebih tinggi dibandingkan dengan peningkatan ekspor. Yang berarti tidak ada peningkatan daya saing di Indonesia akibat adanya depresiasi nilai tukar.

Tabel 1: Analisis ECM Model Agregat Neraca Perdagangan

\begin{tabular}{lccc}
\hline Variabel & Koefisien & Probabilitas & Signifikan \\
\hline Jangka Panjang & & & \\
LN_XM(-1) & $-8,034400$ & 0,0000 & Signifikan \\
LN_NEER(-1) & 1,000137 & 0,0001 & Signifikan \\
LN_GDP(-1) & 7,667905 & 0,0000 & Signifikan \\
LN_GDPFORE(-1) & 0,902518 & 0,0000 & Signifikan \\
\hline Jangka Pendek & & & \\
D(LN_NEER) & $-0,208858$ & 0,0000 & Signifikan \\
D(LN_GDP) & 0,058483 & 0,1178 & tidak \\
D(LN_GDPFORE) & 0,091054 & 0,0861 & tidak \\
\hline
\end{tabular}

Selain menggunakan analisis ECM, digunakan pula analisis menggunakan VECM untuk melihat dampak shock error (volatil) nilai tukar terhadap neraca perdagangan. Dari hasil tersebut dapat melihat dampak dari shock nilai tukar terhadap neraca perdagangan melalui impulse response function. Dapat dilihat 
bahwa (volatil) pada awalnya respons neraca perdagangan terhadap depresiasi nilai tukar diawali dengan negatif namun kemudian direspons secara positif (J-Curve). Akan tetapi pada J-Curve terlihat bahwa respons positif kemudian diikuti kembali oleh respons negatif pada periode setelah kuartal ke-6.

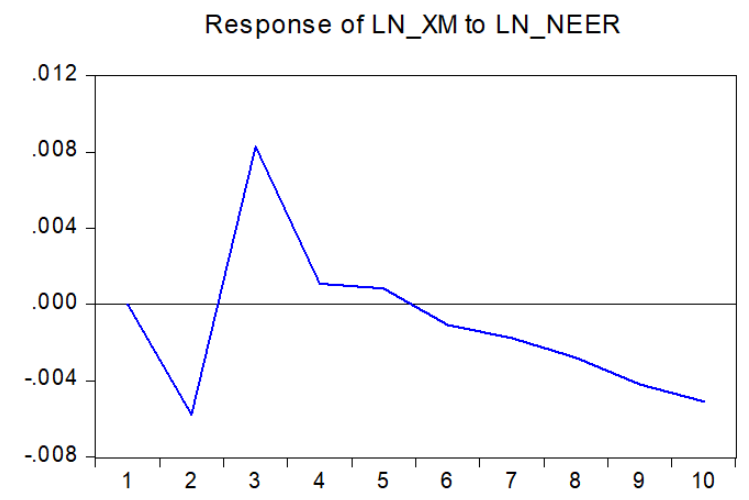

Gambar 1: Respons Neraca Perdagangan terhadap Guncangan Depresiasi Nilai Tukar Sebesar Satu Standar Deviasi

\subsection{Dampak Perang Dagang terhadap Nilai Tukar Rupiah}

Tendensi pelemahan nilai tukar Rupiah terhadap uang AS (USD) lebih disebabkan oleh external factors di mana Dollar USD menguat tajam terhadap semua mata uang dunia atau mengalami penguatan secara meluas (broadbased), termasuk Rupiah. Bank Indonesia (2018) menyatakan bahwa fenomena tersebut dipicu oleh meningkatnya yield US treasury bills mendekati level psikologis 3,0\% dan munculnya kembali ekspektasi kenaikan suku bunga Fed Fund Rate (FFR) sebanyak lebih dari 3 kali selama 2018. Kenaikan yield dan suku bunga di AS itu sendiri dipicu oleh meningkatnya optimisme investor terhadap prospek ekonomi Amerika Serikat seiring berbagai data ekonomi Amerika Serikat yang terus membaik dan tensi perang dagang antara AS dan Cina yang berlangsung selama tahun 2018. Selain itu, kenaikan harga minyak, eskalasi tensi geopolitik terhadap berlanjutnya arus keluar asing dari pasar SBN dan saham Indonesia, kenaikan permintaan valas oleh korporasi domestik terkait kebutuhan pembayaran impor, Utang Luar Negeri, serta dividen yang biasanya cenderung meningkat pada triwulan II juga merupakan faktor internal yang diduga memberikan pengaruh terhadap pelemahan nilai tukar Rupiah.

Dalam melihat faktor struktural penyebab pelemahan nilai tukar rupiah dilakukan dua teknis analisis, pertama, yaitu melakukan regresi dengan memperhatikan faktor ekstrenal dan internal dengan data harian. Faktor eksternal menggunakan dua pendekatan, yaitu federal fund rate dan harga minyak mentah 
dunia, sedangkan faktor internal menggunakan pendekatan Jakarta interbank outstanding rate (JIBOR). Sedangkan, untuk melihat dampak trade war dilakukan juga pendekatan dengan memasukkan nilai Yuan terhadap US dollar sebagai proksinya.

Tabel 2 menunjukkan didapatkan sebagian besar faktor yang memengaruhi depresiasi nilai tukar rupiah berasal dari faktor eksternal, yaitu kenaikan harga minyak mentah dunia dan juga kenaikan federal fund rate maupun nilai Yuan terhadap US dollar. Dapat dilihat Jakarta interbank outstanding rate (JIBOR) tidak signifikan memengaruhi depresiasi nilai tukar pada periode lag 1 sampai 3. Sebaliknya, harga minyak dunia meningkat baru direspons oleh nilai tukar pada hari (lag) ketiga. Hal tersebut dapat dilihat hanya pada lag ketiga harga minyak dunia yang signifikan. Berbeda dengan federal fund rate yang langsung memengaruhi depresiasi rupiah 1 hari setelah kenaikan federal fund rate yang dilihat dari signifikansi federal fund rate pada lag 1.

Tabel 2: Faktor-faktor yang Memengaruhi Depresiasi Nilai Tukar Rupiah (Pendekatan OLS)

\begin{tabular}{lrr}
\hline Variabel & Tanpa Trade War & Dengan Trade War \\
\hline JBOR(-1) & 0,007266 & 0,0012 \\
JBOR(-2) & 0,009380 & $-0,0027$ \\
JBOR(-3) & 0,005653 & 0,0024 \\
LNOIL(-1) & 0,024504 & 0,0220 \\
LNOIL(-2) & $-0,075784$ & $0,013437^{*}$ \\
LNOIL(-3) & $0,090972^{*}$ & $-0,0072$ \\
FRR(-1) & $0,017208^{*}$ & 0,0047 \\
FRR(-2) & 0,000277 & $-0,0048$ \\
FRR(-3) & $-0,032044$ & $-0,0065$ \\
LNER(-1) & $0,585164^{*}$ & $0,900087^{*}$ \\
LNER(-2) & $-0,444408$ & 0,0288 \\
LNER(-3) & $0,834669^{*}$ & $-0,1070$ \\
LNYUAN(-1) & & $0,394941^{*}$ \\
LNYUAN(-2) & & $-0,445714^{*}$ \\
LNYUAN(-3) & & 0,0615 \\
\hline
\end{tabular}

Hasil yang berbeda ditunjukkan ketika dimasukkan variabel yuan terhadap dolar. Secara garis besar, hubungan antara nilai tukar yuan terhadap US dollar berhubungan positif dimana ketika Cina melakukan devaluasi mata uang, maka akan menyebabkan depresiasi nilai tukar. Memasukkan variabel mata uang Cina dalam model membuat beberapa variabel yang awalnya memiliki pengaruh yang signifikan menjadi tidak signifikan. Variabel tersebut yaitu FRR dari hasil tersebut dampak dari mata uang Cina memberikan pengaruh yang cukup tinggi.

Sedangkan, untuk menangkap bagaimana respons dari nilai tukar rupiah terhadap shock eksternal dan internal digunakan metode vector error correction model (VECM) dengan menggunakan dua kuartalan. Untuk menangkap respons nilai tukar terhadap ekspor dan impor itu sendiri ditambahkan variabel ekspor dan impor. Selain itu, digunakan juga indeks harga saham gabungan sebagai proksi kapital yang merupakan penggambaran kondisi investasi di Indonesia. 
Hasil VECM dapat dilihat pada Tabel 3.

Dalam jangka pendek, pergerakan nilai tukar dipengaruhi oleh nilai indeks harga saham gabungan dan juga federal fund rate di mana kenaikan harga saham gabungan menjadi sinyal gambaran kondisi perbaikan pasar saham di Indonesia. Hal tersebut akan direspons dengan penguatan (apresiasi) nilai tukar. Sebaliknya, ketika federal fund rate meningkat, maka pemilik modal akan lebih memilih untuk menginvestasikan modalnya kepada AS yang berdampak pada penguatan nilai tukar USD. Sebaliknya, hal tersebut akan berdampak pada terdepresiasi mata uang rupiah. Pada jangka panjang, faktor yang memengaruhi nilai tukar rupiah adalah ekspor, impor, dan federal fund rate. Peningkatan nilai ekspor akan mengapresiasikan rupiah, sebaliknya peningkatan impor akan mendepresiasikan rupiah.

Tabel 3: Faktor-faktor yang Memengaruhi Depresiasi Nilai Tukar (Pendekatan VECM)

\begin{tabular}{lrr}
\hline Variabel & Tanpa Trade War & Dengan Trade War \\
\hline Jangka Panjang & & \\
LNEXPORT(-1) & $-8,0344^{*}$ & 2,2721 \\
LNIHSG(-1) & 1,000137 & 0,0000 \\
LNIMPORT(-1) & $7,667905^{*}$ & 2,5630 \\
LNMINYAK(-1) & 0,902518 & $1,3333^{*}$ \\
FED & $0,20594^{*}$ & $0,0816^{*}$ \\
LNYUAN(-1) & & $0,0511^{*}$ \\
Cointeq & $-0,019244^{*}$ & $-0,0450^{*}$ \\
\hline Jangka Pendek & & \\
D(LNEXPORT(-1)) & 0,18723 & 0,0859 \\
D(LNIHSG(-1)) & $-0,134226^{*}$ & $-0,0000^{*}$ \\
D(LNIMPORT(-1)) & $-0,10627$ & 0,0436 \\
D(FED(-1)) & $0,011057^{*}$ & 0,0026 \\
D(LNMINYAK(-1)) & $-0,014165$ & $-0,0493$ \\
D(LNYUAN(-1) & & 0,0002 \\
\hline
\end{tabular}

Hasil yang sama juga didapatkan apabila proksi dari trade war dimasukkan ke dalam model. Di mana dalam jangka panjang variabel yang memengaruhi sebagian besar berasal dari eksternal, yaitu federal fund rate, harga minyak dunia, dan juga nilai mata uang yuan terhadap US dollar. Pengaruh nilai mata uang cukup tinggi di mana dibuktikan dengan pengurangan nilai koefisien jangka panjang pada masing-masing variabel.

Untuk melihat faktor mana yang memiliki dampak terkuat terhadap pergerakan nilai tukar rupiah, dilakukan impuls response function dimana masing-masing eror dari variabel dilakukan shock sebesar satu standar deviasi. Hasil menunjukkan bahwa respons yang diberikan nilai tukar terkuat yaitu impor sebagai faktor internal dan diikuti oleh federal fund rate pada kasus tanpa proksi trade war. Namun hasil yang berbeda jika dimasukkan trade war di mana hampir faktor internal pengaruhnya menjadi lebih sedikit. Sebaliknya, faktor yang memengaruhi paling tinggi yaitu federal fund rate dan nilai tukar mata uang yuan terhadap USD yang memiliki pengaruh yang hampir sama kuatnya dengan impor. Hasil IRF 
dapat dilihat pada Gambar 2.

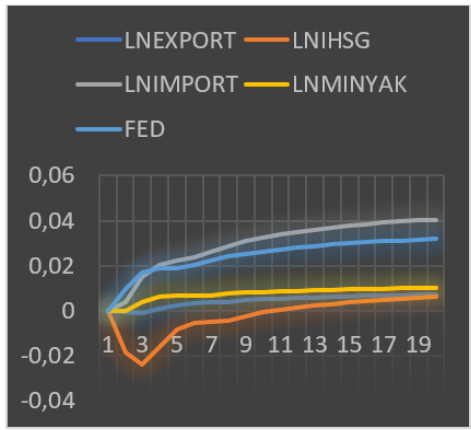

(i) Tanpa Trade War

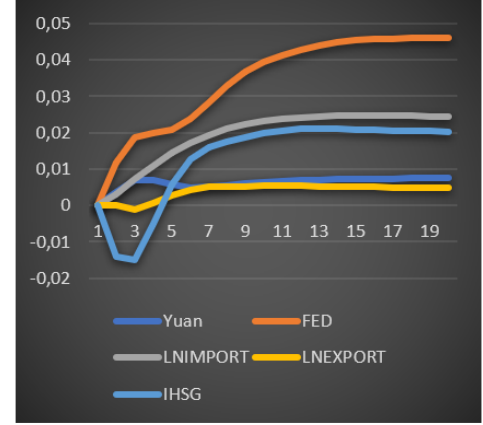

(ii) Trade War

Gambar 2: Respons Nilai Tukar Rupiah terhadap Faktor-faktor yang Memengaruhinya

\subsection{Pengaruh Nilai Tukar dan Faktor lainnya terhadap Ekspor: Analisis Panel Spasial}

Bagian ini membahas pendekatan ekonometrika lainnya, yaitu regresi panel spasial untuk menganalisis faktor-faktor yang memengaruhi ekspor, dengan pendekatan yang dimodifikasi dari model gravity yang mampu menangkap interaksi perdagangan bilateral. Variabel bebas dalam penelitian ini antara lain GDP, nilai tukar, dan tarif. Nilai tukar diukur sebagai rasio nilai tukar negara tujuan relatif terhadap nilai tukar Rupiah. Peningkatan nilai variabel tersebut mengartikan terjadinya depresiasi dari mata uang negara tujuan atau sebaliknya apresiasi dari Rupiah. Selanjutnya, variabel tarif mencerminkan besaran hambatan perdagangan yang diterapkan negara tujuan terhadap Indonesia. Negara tujuan dalam penelitian adalah 30 negara tujuan ekspor terbesar Indonesia, dengan total share lebih dari 90\% total ekspor Indonesia.

Pemodelan regresi panel diawali dari yang paling sederhana, yaitu regresi panel statis tanpa pengaruh spasial. Hasil uji cross-section dependence dengan uji LM menunjukkan bahwa terdapat interaksi antar cross-section yang signifikan sehingga pemodelan dengan regresi panel statis saja tidak cukup. Selanjutnya dilakukan pemodelan regresi panel spasial dengan pembobot kondisi geografis (matriks invers jarak) dan hubungan ekonomi (total perdagangan) serta model regresi Spatial Autoregressive dan Spatial Durbin. Hasilnya berdasarkan ukuran kebaikan model root mean square error (RMSE) dan Akaike information criterion (AIC), model regresi panel spasial Durbin dengan matriks pembobot total perdagangan adalah model terbaik. Hasil selengkapnya dapat dilihat pada Tabel 4.

Pembahasan diawali dari pengaruh lag spasial variabel dependen $(\rho)$, dengan koefisien yang positif dan signifikan dengan nilai 0,7924 . Pengaruh positif ini 
Tabel 4: Analisis Beberapa Model Panel Spasial

\begin{tabular}{|c|c|c|c|c|c|}
\hline Model & $\begin{array}{l}\text { Panel Statis } \\
\text { (fixed effects } \\
\text { model) }\end{array}$ & $\begin{array}{l}\text { Panel Spasi- } \\
\text { al (fixed effe- } \\
\text { cts SAR) (w } \\
=\text { invers ja- } \\
\text { rak) }\end{array}$ & $\begin{array}{l}\text { Panel Spasi- } \\
\text { al (fixed effe- } \\
\text { cts SDM) (w } \\
=\text { invers ja- } \\
\text { rak) }\end{array}$ & $\begin{array}{l}\text { Panel Spasi- } \\
\text { al (fixed effe- } \\
\text { cts SAR) (w } \\
=\text { total per- } \\
\text { dagangan) }\end{array}$ & $\begin{array}{l}\text { Panel Spasi- } \\
\text { al (fixed effe- } \\
\text { cts SDM) (w } \\
=\text { total per- } \\
\text { dagangan) }\end{array}$ \\
\hline \multicolumn{6}{|c|}{ Variabel dependen: Ln_Ekspor } \\
\hline Rho & & $\begin{array}{l}0,6390 \\
(0,0000)^{* * *}\end{array}$ & $\begin{array}{l}0,7626 \\
(0,0000)^{* * *}\end{array}$ & $\begin{array}{l}0,6303 \\
(0,0000)^{* * *}\end{array}$ & $\begin{array}{l}0,7924 \\
(0,0000)^{* * *}\end{array}$ \\
\hline Ln_GDP & $\begin{array}{l}1,9676 \\
(0,0000)^{* * *}\end{array}$ & $\begin{array}{l}0,7722 \\
(0,0000)^{* * *}\end{array}$ & $\begin{array}{l}1,0413 \\
(0,0000)^{* * *}\end{array}$ & $\begin{array}{l}0,9288 \\
(0,0000)^{* * *}\end{array}$ & $\begin{array}{l}1,1756 \\
(0,0000)^{* * *}\end{array}$ \\
\hline Ln_ER & $\begin{array}{l}0,0153 \\
(0,5510)\end{array}$ & $\begin{array}{l}0,1281 \\
(0,0000)^{* * *}\end{array}$ & $\begin{array}{l}0,1139 \\
(0,0000)^{* * *}\end{array}$ & $\begin{array}{l}0,0960 \\
(0,0000)^{* * *}\end{array}$ & $\begin{array}{l}0,0906 \\
(0,0000)^{* * *}\end{array}$ \\
\hline Ln_Tarif & $\begin{array}{l}-0,0379 \\
(0,0000)^{* * *}\end{array}$ & $\begin{array}{l}-0,0351 \\
(0,0000)^{* * *}\end{array}$ & $\begin{array}{l}-0,0409 \\
(0,0000)^{* * *}\end{array}$ & $\begin{array}{l}-0,0392 \\
(0,0000)^{* * *}\end{array}$ & $\begin{array}{l}-0,0431 \\
(0,0000)^{* * *}\end{array}$ \\
\hline w. Ln_GDP & & & $\begin{array}{l}-0,4610 \\
(0,0009)^{* * *}\end{array}$ & & $\begin{array}{l}-0,6182 \\
(0,0000)^{* * *}\end{array}$ \\
\hline w. Ln_ER & & & $\begin{array}{l}-0,0537 \\
(0,4693)\end{array}$ & & $\begin{array}{l}-0,1513 \\
(0,2516)\end{array}$ \\
\hline w. Ln_Tarif & & & $\begin{array}{l}0,0450 \\
(0,0003)^{* * *}\end{array}$ & & $\begin{array}{l}0,0493 \\
(0,0000)^{* * *}\end{array}$ \\
\hline uji LM & chisq $=2506$ & $\left(p-\right.$ value $\left.=0,0000^{* * *}\right)$ & & & \\
\hline $\mathrm{R}^{2}$ (pseudo) & 0,7686 & 0,9693 & 0,9716 & 0,9693 & 0,9731 \\
\hline RMSE & 0,2859 & 0,2201 & 0,2117 & 0,2204 & 0,2062 \\
\hline AIC & 198,2392 & $-98,0490$ & $-136,2853$ & $-96,4992$ & $-166,1727$ \\
\hline
\end{tabular}

Keterangan: Nilai dalam ( ) adalah $p$-value.

$* * *, * * *$ signifikan pada taraf nyata $1 \%, 5 \%, 10 \%$.

menunjukkan nilai ekspor dari Indonesia ke suatu negara mitra dipengaruhi juga oleh besarnya perdagangan yang terjadi antar negara mitra ekspor Indonesia itu sendiri. Makin besar perdagangan yang terjadi di antara negara mitra, maka makin besar juga nilai ekspor Indonesia ke negara-negara mitra tersebut. Hal ini menunjukkan keterbukaan perdagangan (trade openness) yang lebih tinggi. Lebih lanjut, pengaruh lag spasial yang signifikan juga menunjukkan pentingnya menyertakan pengaruh spasial dalam analisis di level antar negara. Hasil ini juga sesuai dengan hipotesis dan teori yang diajukan bahwa ketergantungan spasial sering terdapat pada sampel cross section (LeSage \& Pace, 2009). Selanjutnya tiga variabel bebas yaitu GDP, nilai tukar, dan tarif, semuanya berpengaruh signifikan terhadap ekspor.

Variabel GDP memiliki koefisien yang positif dengan nilai variabel yang terbesar dibandingkan dengan variabel lain. Artinya, makin besar ukuran ekonomi (GDP) negara tujuan, maka makin besar ekspor Indonesia menuju negara tersebut. Hasil ini sangatlah relevan karena ukuran ekonomi dapat menunjukkan kemampuan absorpsi dari negara mitra terhadap produk dari Indonesia. Dari nilai koefisien GDP yang terbesar juga dapat dikatakan GDP memiliki pengaruh yang paling besar dibandingkan dengan determinan lainnya. Selain itu, hasil tersebut juga sejalan dengan fakta bahwa empat negara tujuan ekspor terbesar Indonesia dengan share lebih dari $40 \%$ total ekspor, yaitu Cina, Jepang, Amerika 
Serikat, dan India, merupakan negara anggota G20.

Nilai tukar memiliki pengaruh signifikan dan positif terhadap ekspor. Tanda positif menunjukkan bahwa kenaikan atau apresiasi Rupiah berdampak pada peningkatan ekspor. Hasil ini terlihat berlawanan dengan teori competitiveness yang banyak dibahas dalam literatur perdagangan internasional. Akan tetapi, temuan ini dapat dikatakan sejalan dengan hasil yang diperoleh dari analisis J-Curve dengan metode VECM di bagian sebelumnya. Gambar 1 menunjukkan bahwa hubungan nilai tukar rupiah dan neraca perdagangan Indonesia secara agregat mengikuti fenomena J-Curve, yaitu neraca perdagangan merespons negatif depresiasi nilai tukar pada jangka pendek kemudian diikuti oleh respons positif, akan tetapi kembali diikuti respons negatif. Dengan pengagregasian menggunakan model regresi, pengaruh negatif depresiasi terhadap neraca perdagangan lebih banyak dibandingkan pengaruh positifnya. Atau sebaliknya, pengaruh apresiasi nilai tukar lebih dominan positif terhadap ekspor.

Adanya hambatan perdagangan (yang direpresentasikan dengan tarif) memiliki pengaruh negatif terhadap ekspor Indonesia. Temuan tersebut didasarkan pada koefisien dari tarif yang negatif dan signifikan secara statistik. Temuan tersebut menunjukkan hambatan perdagangan, yaitu tarif impor merupakan faktor penting yang dapat menghambat ekspor serta menyiratkan pentingnya upaya Indonesia untuk bernegosiasi dengan negara mitra tujuan ekspor untuk menurunkan hambatan perdagangannya. Bukti empiris terkait tarif juga dapat diinterpretasikan bahwa ekspor Indonesia dapat lebih diarahkan kepada negara-negara yang telah memberikan tarif lebih rendah.

Pengaruh dari lag spasial variabel bebas memiliki tanda yang berlawanan dengan variabel bebasnya. Ini adalah temuan menarik dan dapat dijelaskan sebagai berikut. Pengaruh lag spasial GDP yang negatif menunjukkan bahwa makin besar GDP negara tetangga dari negara mitra ekspor, maka ekspor Indonesia ke negara mitra tersebut menurun. Posisi negara tetangga tersebut adalah kompetitor bagi negara mitra, karena bisa jadi ekspor Indonesia ke negara mitra beralih ke negara tetangganya. Kondisi serupa juga terjadi pada variabel tarif. Pengaruh lag spasial tarif secara statistik signifikan dan positif. Artinya, makin besar hambatan tarif yang ditetapkan oleh tetangga dari negara mitra, maka ekspor Indonesia ke negara mitra tersebut meningkat. Atau sebaliknya, ekspor dari Indonesia ke suatu negara mitra akan menurun jika negara tetangga (kompetitornya) mampu memberikan tarif yang lebih rendah untuk produk Indonesia.

\subsection{Identifikasi Pengembangan Industri Berorientasi Ekspor}

Tabel 5 menggambarkan dampak simulasi terhadap output untuk sektor yang memperlihatkan respons surplus neraca perdagangan atau dapat diklasifikasikan sebagai "winner" dari skenario kebijakan. Secara logis, sektor-sektor orientasi ekspor akan meningkatkan kapasitas untuk mengekspor akibat peluang dari depresiasi. Kemudian, akan mengubah utilisasi impor dengan menurunkan tingkat impor. Kondisi ini akan menekan harga output ke level yang lebih rendah 
di pasar domestik. Mekanisme respons seperti demikian terjadi pada hampir seluruh subsektor low and medium technological manufacturing, dan mayoritas subsektor jasa-jasa. Respons yang baik juga ditunjukkan oleh sektor-sektor yang berorientasi ekspor, memiliki nilai tambah, serta daya saing yang tinggi.

Tabel 5: Winning Sectors Akibat Pergerakan Nilai Tukar Rupiah

\begin{tabular}{|c|c|c|c|}
\hline Sektor & $\begin{array}{l}\text { Neraca Perda- } \\
\text { gangan (Mili- } \\
\text { ar USD) }\end{array}$ & Sektor & $\begin{array}{l}\text { Neraca Perda- } \\
\text { gangan (Mili- } \\
\text { ar USD) }\end{array}$ \\
\hline Produk Kimia, Karet, dan Plastik & 15,64 & Konstruksi & 0,09 \\
\hline Jasa Administrasi $\quad \mathrm{Pu}-$ & 6,46 & Jasa Transportasi Udara & 0,09 \\
\hline blik/Pertahanan/ & & & \\
\hline Kesehatan /Pendidikan & & & \\
\hline Minyak Nabati dan Hewani & 6,18 & Air & 0,05 \\
\hline Pakaian Jadi & 5,95 & Rekreasi dan Jasa Lainnya & 0,04 \\
\hline Produk Kulit & 5,58 & $\begin{array}{l}\text { Manufaktur Gas dan Distri- } \\
\text { busi }\end{array}$ & 0,01 \\
\hline Produk Kertas dan Percetakan & 5,07 & & \\
\hline Produk Kayu & 4,11 & & \\
\hline Tekstil & 2,43 & & \\
\hline Produk Elektronik & 2,19 & & \\
\hline Mineral Non Metal & 1,11 & & \\
\hline Jasa Transportasi Lainnya & 0,97 & & \\
\hline Produk Metal & 0,77 & & \\
\hline Jasa Bisnis & 0,35 & & \\
\hline Asuransi & 0,20 & & \\
\hline Daging hewani lainnya & 0,11 & & \\
\hline
\end{tabular}

Sintesis yang dapat dikemukakan terkait dengan hasil sektoral simulasi GTAP adalah depresiasi nilai tukar rupiah akan meningkatkan neraca perdagangan beberapa kelompok industri, meskipun disertai dengan pengaruh faktor import content. Kelompok industri tersebut secara berurutan dari pengaruh yang paling besar terhadap neraca perdagangan adalah sebagai berikut: Industri kimia, karet dan plastik; Industri lemak dan minyak nabati (CPO); Industri tekstil dan pakaian jadi; Industri kulit; Industri kertas dan olahan kayu; Industri elektronik; Industri logam; dan Industri mineral non logam. Seluruh industri tersebut diseleksi sebagai sektor terpilih yang selanjutnya akan dianalisis dengan J-Curve sektoral melalui pendekatan ekonometrika.

Berdasarkan aspek sektoral, fenomena J-Curve berbeda-beda antar sektor yang dianalisis. Secara garis besar, mayoritas besar sektor unggulan di Indonesia memiliki fenomena J-Curve yang dibuktikan dari estimasi ECM. Dari 8 produk yang dianalisis dapat dikelompokkan menjadi 4 kelompok. Kelompok pertama fenomena J-Curve diikuti sepenuhnya: karet dan plastik; kertas dan olahan kayu; tekstil dan pakaian jadi; dan minyak sawit. Hasil ECM pada kelompok pertama dapat dilihat pada Tabel 6.

Secara garis besar, dengan adanya depresiasi rupiah terdapat beberapa sektor yang mengalami kerugian dan keuntungan. Sektor yang mengalami kerugian yaitu sektor yang sebagian besar bahan baku berasal dari impor dan juga sektor 
Tabel 6: Hasil Estimasi Sektor yang Mengalami J-Curve Penuh

\begin{tabular}{|c|c|c|c|c|c|c|c|c|}
\hline \multirow[t]{2}{*}{ Variabel } & \multicolumn{2}{|c|}{$\begin{array}{c}\text { Karet dan } \\
\text { Plastik }\end{array}$} & \multicolumn{2}{|c|}{ Minyak Sawit } & \multicolumn{2}{|c|}{$\begin{array}{c}\text { Kertas dan } \\
\text { Olahan Kayu }\end{array}$} & \multicolumn{2}{|c|}{$\begin{array}{l}\text { Tekstil dan } \\
\text { Pakaian jadi }\end{array}$} \\
\hline & Koef. & Prob. & Koef. & Prob. & Koef. & Prob. & Koef. & Prob. \\
\hline Jangka Pendek & & & & & & & & \\
\hline D(LN_NEER) & 1,5517 & 0,0002 & 2,5428 & 0,0000 & 0,6302 & 0,0000 & $-0,4640$ & 0,1364 \\
\hline D(LN_GDPFORE) & $-1,0015$ & 0,0005 & $-2,3305$ & 0,0000 & $-0,2021$ & 0,0000 & 0,2442 & 0,0672 \\
\hline D(LN_GDP) & 0,5246 & 0,0007 & 2,1114 & 0,0000 & 0,7383 & 0,0000 & $-1,2205$ & 0,0000 \\
\hline D(LN_Reserve) & 1,0579 & 0,0000 & 2,0824 & 0,0000 & 0,1768 & 0,0017 & $-0,6884$ & 0,0000 \\
\hline ECT & $-0,1721$ & 0,0000 & $-0,3827$ & 0,0000 & $-0,4137$ & 0,0000 & $-0,1722$ & 0,0000 \\
\hline $\mathrm{C}$ & 0,0658 & 0,0000 & 0,0232 & 0,0000 & $-0,0218$ & 0,0001 & 0,0448 & 0,0002 \\
\hline Jang & & & & & & & & \\
\hline LN_NEER & 7,2394 & 0,0001 & 7,4495 & 0,0006 & 3,7264 & 0,0000 & 1,0332 & 0,0000 \\
\hline LN_GDPFORE & 4,3175 & 0,0000 & 4,9080 & 0,0000 & 2,1869 & 0,0000 & 0,1147 & 0,2425 \\
\hline LN_GDP & $-3,2255$ & 0,0002 & $-3,9981$ & 0,0049 & $-2,2302$ & 0,0000 & $-1,5834$ & 0,0000 \\
\hline LN_Reserve & 0,6121 & 0,3503 & 1,3624 & 0,2823 & 0,2810 & 0,4675 & 0,3312 & 0,0000 \\
\hline $\mathrm{C}$ & $-52,2661$ & 0,0001 & $-58,0687$ & 0,0000 & $-19,6252$ & 0,0000 & 9,9205 & 0,0000 \\
\hline
\end{tabular}

yang memiliki nilai tambah yang sedikit dari bahan baku seperti kulit dan metal. Namun akan menguntungkan bagi industri seperti vegetable oil yang sebagain besar bahan baku berasal dari dalam negeri. Dalam jangka panjang, industri vegetable oil memiliki koefisien yang positif antara nilai tukar dengan neraca perdagangan. Hasil yang sama juga terjadi pada kasus Industri karet dan plastik. Industri karet di Indonesia pada jangka panjang akan mengalami neraca perdagangan positif dari depresiasi nilai tukar (J-Curve). Begitupun dengan Industri kertas dan olahan kayu yang mengalami dampak positif dari terjadinya depresiasi nilai tukar di jangka pendek ataupun panjang.

Tekstil dan pakaian jadi di Indonesia merupakan salah satu sektor ekspor unggulan. Hasil ECM menunjukkan bahwa pada jangka pendek sektor ini akan mengalami penurunan neraca perdagangan akibat dari sebagian besar komponen produksi masih berasal dari impor. Namun, dalam jangka panjang terdapat penyesuaian sehingga dalam jangka panjang penurunan nilai tukar memberikan daya saing bagi ekspor tekstil kita sehingga memberikan pengaruh yang positif terhadap neraca perdagangan.

Sedangkan, fenomena J-Curve diikuti pada jangka panjang saja, yaitu elektronik dan industri logam di mana kedua produk ini hanya memperoleh dampak positif pada neraca perdagangan pada jangka panjang. Hasil ECM pada kelompok ini berada pada Tabel 7 .

Pada kasus logam dan elektronik, yaitu pada sektor Electronic equipment dan Machinery and equipment nec, terdapat hubungan positif antara nilai tukar dengan neraca perdagangan. Hal ini dikarenakan dengan adanya depresiasi nilai tukar membuat barang-barang elektronik impor yang biasanya sudah menjadi barang jadi menjadi lebih mahal. Hal ini membuat keinginan konsumen untuk membeli barang menjadi lebih rendah sehingga impor akan menurun dan berujung pada peningkatan neraca perdagangan. 
Tabel 7: Sektor yang Mengalami J-Curve pada Jangka Panjang

\begin{tabular}{lcc|cc}
\hline \multirow{2}{*}{ Variabel } & Elektronik & & Industri Logam & \\
\cline { 2 - 5 } & Koef. & Prob. & Koef. & Prob. \\
\hline Jangka Pendek & & & & \\
D(LN_NEER) & 1,3053 & 0,4812 & 1,0607 & 0,3088 \\
D(LN_GDPFORE) & $-0,1937$ & 0,8277 & $-0,6528$ & 0,2538 \\
D(LN_GDP) & 1,1696 & 0,1900 & 0,9000 & 0,0264 \\
D(LN_Reserve) & 0,0796 & 0,8931 & 0,3596 & 0,4528 \\
ECT & $-0,2497$ & 0,0704 & $-0,3439$ & 0,0094 \\
C & $-0,0051$ & 0,9048 & $-0,0165$ & 0,5382 \\
\hline Jangka Panjang & & & & \\
LN_NEER & 8,9532 & 0,0000 & 4,9124 & 0,0000 \\
LN_GDPFORE & 5,5596 & 0,0000 & 2,7320 & 0,0000 \\
LN_GDP & $-4,2772$ & 0,0000 & $-3,0109$ & 0,0000 \\
LN_Reserve & 0,3551 & 0,6163 & 0,5918 & 0,2292 \\
C & $-60,3375$ & 0,0000 & $-25,9101$ & 0,0000 \\
\hline
\end{tabular}

Kelompok ketiga yaitu fenomena J-Curve tidak terjadi pada sektor kulit. Di mana pada sektor ini depresiasi nilai tukar justru berpengaruh negatif terhadap neraca perdagangan. Hasil estimasi ECM kelompok ini dapat dilihat pada Tabel 8.

Tabel 8: Hasil Estimasi ECM Sektor yang Tidak Mengalami J-Curve

\begin{tabular}{lcc}
\hline \multirow{2}{*}{ Variabel } & \multicolumn{2}{c}{ Kulit } \\
\cline { 2 - 3 } & Koef. & Prob. \\
\hline Jangka Pendek & & \\
D(LN_NEER) & 2,9061 & 0,0679 \\
D(LN_GDPFORE) & $-3,0939$ & 0,0009 \\
D(LN_GDP) & $-0,2139$ & 0,6904 \\
D(LN_Reserve) & 0,7588 & 0,2931 \\
ECT & $-0,1200$ & 0,1352 \\
C & $-0,0020$ & 0,9604 \\
\hline Jangka Panjang & & \\
LN_NEER & $-3,5719$ & 0,0464 \\
LN_GDPFORE & $-3,4583$ & 0,0001 \\
LN_GDP & $-0,1891$ & 0,8723 \\
LN_Reserve & 0,9777 & 0,3725 \\
C & 50,0001 & 0,0000 \\
\hline
\end{tabular}

Sektor keempat adalah rest sector di mana depresiasi nilai tukar sama sekali tidak memengaruhi neraca perdagangan, baik pada jangka pendek maupun jangka panjang. Sektor tersebut yaitu Mineral non Logam. Hasil estimasi dapat dilihat pada Tabel 9.

Untuk melihat bagaimana dampak nilai tukar terhadap trade balance pada setiap sektor dan kapan titik balik J-Curve pada masing-masing sektor digunakan analisis impulse response function. Hasil analisis impulse response menunjukkan bahwa pada delapan sektor yang digunakan sebagian besar mengalami titik balik J-Curve pada periode (kuartal) ketiga. Namun, tidak semua sektor merespons 
Tabel 9: Rest Sector

\begin{tabular}{lcc}
\hline \multirow{2}{*}{ Variabel } & \multicolumn{2}{c}{ Mineral non Logam } \\
\cline { 2 - 3 } & Koef. & Prob. \\
\hline Jangka Pendek & & \\
D(LN_NEER) & 0,1156 & 0,9351 \\
D(LN_GDPFORE) & $-0,8980$ & 0,2593 \\
D(LN_GDP) & $-0,7287$ & 0,1239 \\
D(LN_Reserve) & 1,2485 & 0,0670 \\
ECT & $-0,5811$ & 0,0001 \\
C & $-0,0201$ & 0,5825 \\
\hline Jangka Panjang & & \\
LN_NEER & $-0,0790$ & 0,9274 \\
LN_GDPFORE & $-1,4396$ & 0,0008 \\
LN_GDP & $-0,4275$ & 0,4636 \\
LN_Reserve & 0,3522 & 0,5149 \\
C & 19,8359 & 0,0004 \\
\hline
\end{tabular}

positif pada periode berikutnya setelah titik balik. Beberapa sektor kembali merespons negatif setelah period (kuartal) kelima. Sektor tersebut yaitu elektronik dan mineral non logam yang merupakan salah satu sektor dengan import content cukup tinggi dan dari hasil ECM untuk mineral non logam merupakan sektor yang termasuk golongan rest sector.

Perubahan ekonomi global berpengaruh secara signifikan pada perekonomian nasional, khususnya kinerja neraca perdagangan. Untuk itu, perlu strategi nasional pengembangan industri berorientasi ekspor untuk mengantisipasi dinamika yang terjadi. Industri yang menunjukkan kebingkasan (resilience) bila ada goncangan nilai tukar rupiah adalah industri berorientasi ekspor yang berbasis sumber daya domestik. Data Statistik Industri Besar dan Sedang menunjukkan bahwa industri yang menjadi unggulan ekspor Indonesia memiliki komponen bahan baku lokal yang lebih dominan.

Strategi industrialisasi yang harus dikembangkan untuk Indonesia (small open economy) dalam rangka pencapaian sasaran makroekonomi, baik neraca internal maupun eksternal, adalah pengembangan industri yang berorientasi ekspor dan intensif tenaga kerja (Salter-Corden model).

\section{Simpulan dan Rekomendasi Kebijakan}

1. Berdasarkan model VECM, hubungan empiris nilai tukar rupiah dan neraca perdagangan Indonesia secara agregat mengikuti fenomena J-Curve. Pada jangka pendek, depresiasi nilai tukar menurunkan neraca perdagangan, sebaliknya pada jangka panjang depresiasi akan meningkatkan neraca perdagangan nasional, walaupun pada periode selanjutnya terdapat lagi perubahan respons neraca perdagangan.

2. Pergerakan nilai tukar rupiah dalam beberapa kurun waktu terakhir lebih disebabkan oleh faktor eksternal, antara lain suku bunga Bank Sentral AS dan harga minyak dunia dibandingkan faktor internal. 


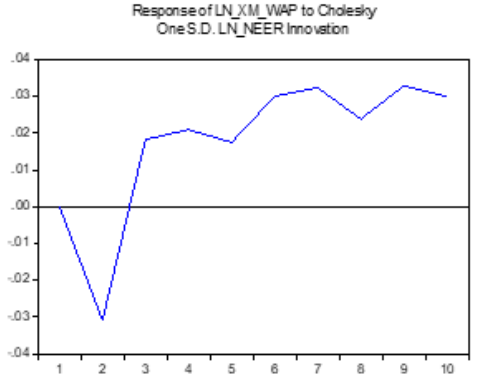

(i) Pakaian Jadi dan Tekstil Response of LN_XM_LUMPPP to Choleshy One S.D. U.N_NEER Imovation

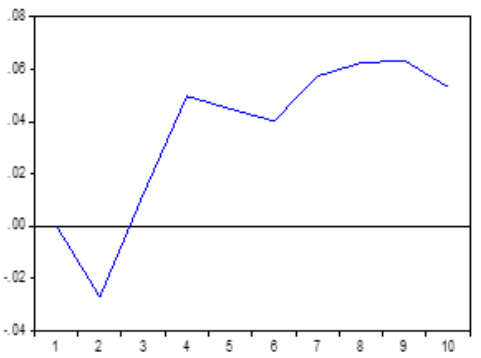

(iii) Kertas dan Olahan Kayu

Res ponse of LN XOM ONE to Choles

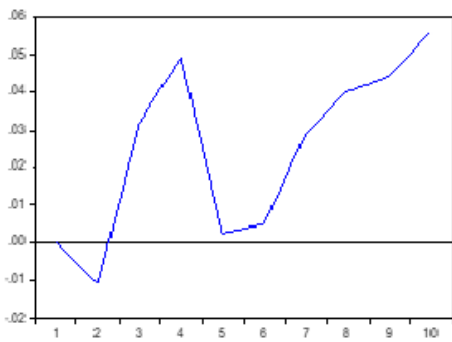

(v) Logam

Response of LN_XM_NFMto Cnoesl One S.D. LN INEER hnovation

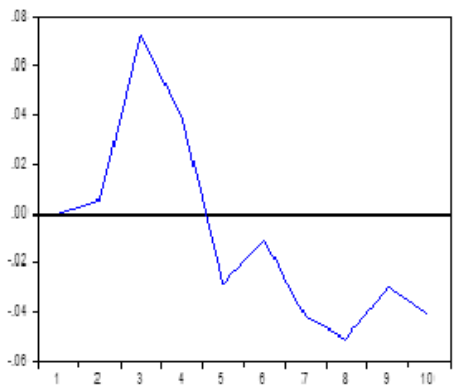

(vii) Mineral non Logam

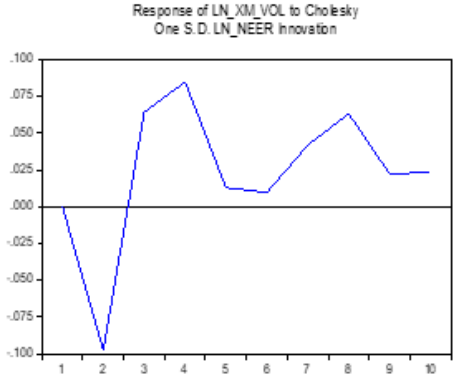

(ii) Minyak Nabati Sawit Res ponse of LN_XM_CRP to Choles One S.D. LN_NEER hnovation

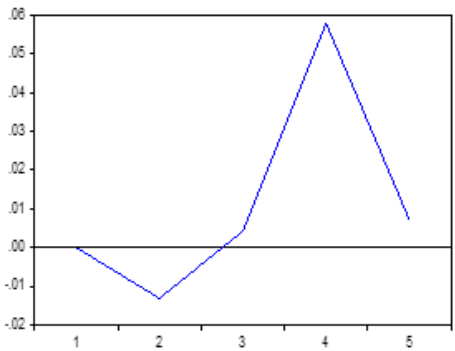

(iv) Karet dan Plastik

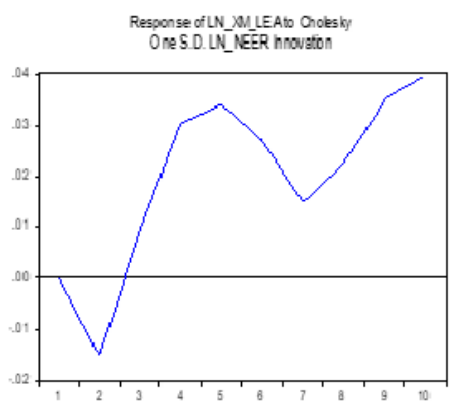

(vi) Kulit

Resoonse of LN XM ELE to Cholesky O neS. D. LN_NEER hnovation

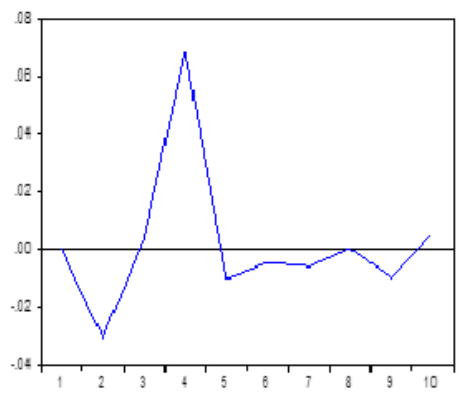

(viii) Elektronik

Gambar 3: Hasil Impulse Response Function Sektor Terpilih 


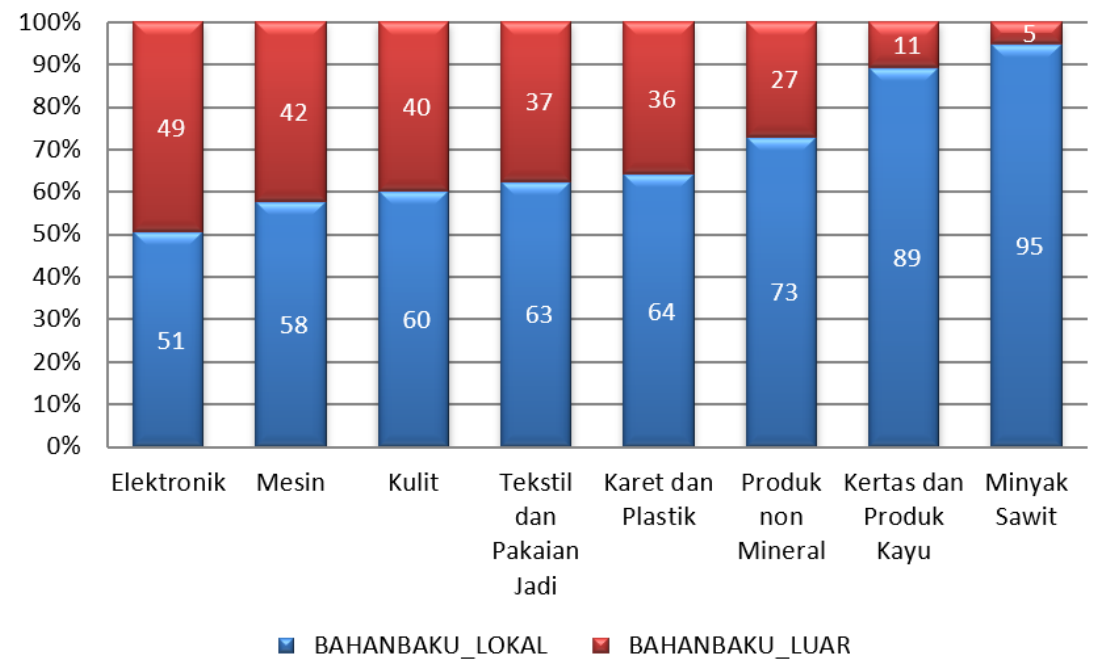

Gambar 4: Komposisi Bahan Baku Lokal dan Impor Beberapa Industri Terpilih Sumber : Statistik Industri Besar dan Sedang, BPS

3. Trade war yang diproksi dengan nilai tukar yuan terhadap USD terbukti memengaruhi depresiasi nilai tukar di mana devaluasi yuan terhadap USD akan berdampak pada terdepresiasinya rupiah

4. Pemodelan regresi panel spasial menunjukkan GDP, nilai tukar, dan tarif berpengaruh signifikan dengan tanda masing-masing positif, positif, dan negatif terhadap nilai ekspor Indonesia. Kemudian, makin besar perdagangan yang terjadi di antara negara mitra, maka makin besar juga nilai ekspor Indonesia ke negara-negara mitra tersebut. Pengaruh lag spasial dari GDP, nilai tukar, dan tarif berlawanan tanda dengan variabel asalnya. Makin besar GDP negara lain, maka ekspor Indonesia ke suatu negara mitra menurun. Makin besar tarif negara lain (kompetitor), maka ekspor Indonesia ke suatu negara mitra meningkat.

5. Secara sektoral, simulasi GTAP menunjukkan bahwa depresiasi nilai tukar rupiah akan meningkatkan neraca perdagangan beberapa kelompok industri, meskipun disertai dengan pengaruh faktor import content. Kelompok industri tersebut secara berurutan dari pengaruh yang paling besar terhadap neraca perdagangan adalah sebagai berikut: Industri kimia, karet dan plastik; Industri lemak dan minyak nabati (CPO); Industri tekstil dan pakaian jadi; Industri kulit; Industri kertas dan olahan kayu; Industri elektronik; Industri logam dan industri mineral non logam.

6. Analisis model ekonometrika menunjukkan 8 sektor yang mempunyai dampak positif tersebut di atas yang dapat dikelompokkan dalam 4 perila$\mathrm{ku}$ : 
a. Kelompok yang mengikuti fenomena J-Curve sepenuhnya yaitu Industri karet dan plastik; Industri lemak dan minyak nabati (CPO); Industri tekstil dan pakaian jadi; serta Industri kertas dan olahan kayu.

b. Fenomena J-Curve hanya diikuti pada jangka panjang, yaitu industri elektronik dan industri logam.

c. Fenomena J-Curve tidak diikuti sepenuhnya, yaitu industri kulit.

d. Rest sector yaitu industri mineral non logam

7. Strategi pengembangan industri yang berorientasi ekspor dan intensif tenaga kerja (Salter-Corden model) memerlukan dukungan pembiayaan dan fasilitasi jasa keuangan lainnya untuk pelaku ekspor.

8. Studi ini memberikan sinyal bahwa daya saing produk Indonesia di pasar global sangat ditentukan oleh faktor suplai (biaya produksi). Terobosan untuk meningkatkan efisiensi, seperti pemetaan industri unggulan berorientasi ekspor menurut sektor dan wilayah, pemetaan masalah dan solusinya di sepanjang rantai pasok sampai efisiensi birokrasi memerlukan perhatian yang lebih serius di masa mendatang.

\section{Daftar Pustaka}

[1] Arbia, G., Basile, R., \& Piras, G. (2005). Using spatial panel data in modelling regional growth and convergence. ISAE Working Papers, 55. Institute for Studies and Economic Analyses (ISAE). https://ebiblio.istat.it/digibib/Working\%20Papers/ WP552005ArbiaPirasBasile.pdf.

[2] Arize, A. C., Osang, T., \& Slottje, D. J. (2000). Exchange-rate volatility and foreign trade: evidence from thirteen LDC's. Journal of Business E Economic Statistics, 18(1), 10-17.

[3] Bahmani-Oskooee, M., \& Kantipong, T. (2001). Bilateral J-curve between Thailand and her trading partners. Journal of Economic Development, 26(2), 107-118.

[4] Bahmani-Oskooee, M., \& Harvey, H. (2009). The J-curve: Indonesia vs. her major trading partners. Journal of Economic Integration, 24(4), 765-777.

[5] Darwanto. (2014). Adakah fenomena Marshall-Lerner condition dan J-Curve di Indonesia. Jurnal Bisnis dan Ekonomi, 21(1), 18-29.

[6] Elhorst, J. P. (2014). Spatial econometrics: from cross-sectional data to spatial panels. Springer.

[7] Enders, W. (2004). Applied econometric time series (2nd edition). New York: John Willey \& Sons.

[8] Jajang, Saefuddin, A., Mangku, I. W., \& Siregar, H. (2013). Analisis kemiskinan menggunakan model panel spasial statik. Mimbar: Jurnal Sosial dan Pembangunan, 29(2), 195-204. doi: https:/ / doi.org/10.29313/mimbar.v29i2.396.

[9] Leigh, D., Lian, W., Poplawski-Ribeiro, M., Szymanski, R., Tsyrennikov, V., \& Yang, H. (2016). Exchange rates and trade: Disconnected? https://www.imf.org/external/np/ seminars/eng/2016/ExchangeRates/pdf/Leigh.pdf.

[10] LeSage, J., \& Pace, R. K. (2009). Introduction to spatial econometrics. Chapman and Hall/CRC. 
[11] Onafowora, O. (2003). Exchange rate and trade balance in East Asia: is there a J-curve. Economics Bulletin, 5(18), 1-13.

[12] Petrović, P., \& Gligorić, M. (2010). Exchange rate and trade balance: J-curve effect. Panoeconomicus, 57(1), 23-41. doi: http://dx.doi.org/10.2298/PAN1001023P.

[13] Ramadona. (2016). Pengaruh perubahan nilai tukar terhadap neraca perdagangan Indonesia (Master Theses, Institut Pertanian Bogor).

[14] Ramakrishnan, U., Martorell, R., Schroeder, D. G., \& Flores, R. (1999). Role of intergenerational effects on linear growth. The Journal of Nutrition, 129(2), 544S-549S. doi: https:/ / doi.org/10.1093/jn/129.2.544S.

[15] Rose, A. K. (1990). Exchange rates and the trade balance: some evidence from developing countries. Economics Letters, 34(3), 271-275. doi: https:/ / doi.org/10.1016/01651765(90)90130-S.

[16] Rose, A. K., \& Yellen, J. L. (1989). Is there a J-curve? Journal of Monetary Economics, 24(1), 53-68. doi: https:/ /doi.org/10.1016/0304-3932(89)90016-0.

[17] Sabuhi-Sabouni, M., \& Piri, M. (2008). Consideration the effect of exchange rate volatility on agricultural products export price, the case study of Iran's saffron. American-Eurasian Journal of Agricultural \& Environmental Sciences, 2(Supple 1), 97100.

[18] Ward, B. D., \& Siregar, H. (2000). The role of aggregate demand shocks in explaining Indonesian macro-economic fluctuations. Commerce Division Discussion Paper, 86. Lincoln University. http:/ /dspace.lincoln.ac.nz/handle/10182/542.

[19] Wilson, P. (2001). Exchange rates and the trade balance for dynamic Asian economies-does the J-curve exist for Singapore, Malaysia, and Korea?. Open Economies Review, 12(4), 389-413. doi: https:/ /doi.org/10.1023/A:1017982901034. 
this page intentionally left blank 